\title{
SEAPORT POSITIONING SUPPORTED BY THE COMBINATION OF SOME QUANTITATIVE AND QUALITATIVE APPROACHES
}

\author{
Sanja Bauk ${ }^{1}$, Senka Šekularac-Ivošević ${ }^{2}$, Natalija Jolić ${ }^{3}$ \\ ${ }^{1,2}$ Faculty of Maritime Studies, University of Montenegro, Montenegro \\ ${ }^{3}$ Faculty of Transportation Science, University of Zagreb, Croatia \\ Submitted 18 June 2012; accepted 23 October 2012; \\ first published online 25 October 2013
}

\begin{abstract}
The ports' management is facing the challenge of sustainable port development, considering several aspects: economic, technological, logistical, environmental, and community involvement. Although the numerous scientific concepts have been developed for explaining the trends of ports' involvement into the logistics chains, this research work presents an attempt to draw the attention to the marketing aspect of the port mission, being focused primarily on the customers' needs, whose preferences are the key factor in selecting specific port in competitive environment. Therefore, the Adriatic, Aegean, and Black Sea ports, sharing the unique marketing features and target market, have been analyzed with the aim to be mutually positioned. The considered ports have similar goals: to achieve the greater degree of competitiveness as well as to acquire the larger number of customers being attracted on the basis of superior port choice criteria. These circumstances have been explored through some distinctive quantitative and qualitative criteria by employing the appropriate, well known and structured quantitative PROMETHEE and AHP method. The obtained results are presented by perception maps, and described on the basis of gained quantitative indicators and the qualitative explanations given by the authors, primarily, in the marketing manner.
\end{abstract}

Keywords: seaport; marketing; positioning; PROMETHEE; AHP.

\section{Introduction}

Expanding the spatial and functional scope of their activities, modern ports represent significant logistical and industrial centers, but they are dominantly related to maritime transport (Noteboom, Yap 2012). Also, ports are the elements of value - driven chain systems (Robinson 2002), i.e. seaports are the link without which, the two modules of transport - maritime and land could not be effectively connected. In a competitive environment, marketing as a concept and port business practice offers a wide range of solutions for achieving and maintaining competitive advantage, which could be expressed as financial (profit) and/or nonfinancial (port image, etc.) parameters. The variety of methods have been applied, many ideas and activities carried out in order to achieve the ultimate goal - to be more competitive in the port services market and to be chosen by users (shippers, forwarders, shipping companies, terminal operators, port authorities, government agencies, and other clients).

For the purpose of developing an efficient marketing (re)positioning strategy for ports, we emphasize here the two basic themes attracting the attention of the scientific and professional community:

- seaport competition and competitiveness;

- the port choice criteria.

Many methods have been used in order to define the factors of seaport competitive performance, but benchmarking is standing out as a method of the marketing positioning of the ports based solely on the comparison and the research aiming to determine, which port is the leader in the market. Rugman and Verbeke (1993) applied the Porter's Diamond in the case of seaports, concluding that a seaport position in the market is based on six key 'diamond' factors. Pando et al. (2005) showed that the benchmarking practice was appropriate and applicable in the case of seaports. Pardali and Michalopoulos (2008) applied the benchmarking method in the case of Mediterranean container ports. Evaluating the competitiveness of container ports in Korea and China, Yeo et al. (2008) made the comprehensive literature review of the port competitiveness components, concluding that port competitiveness is determined by

Corresponding author: Sanja Bauk

E-mail: bsanjaster@gmail.com

Copyright $\odot 2013$ Vilnius Gediminas Technical University (VGTU) Press http://www.tandfonline.com/TRAN 
the port service, hinterland condition, availability, convenience, logistics cost, regional centre and connectivity. Efficiency, shipping frequency, adequate infrastructure, location, port charges, quick response to port users' needs, reputation regarding cargo damage, intermodal and value - added services, information system availability are some of the port selection criteria (Tongzon 1995, 2009; Tongzon, Heng 2005; Murphy et al. 1992; Malchow, Kanafani 2004; Magala, Simmons 2008; Vickery et al. 2003).

There are many quantitative methods that are used to measure the degree of port competitiveness. One of them is linear programming, where a considerable number of authors agree about the most important factors such as: domestic (captive) traffic, good hinterland connections, adequate feeder networks, good infrastructure and competitive port pricing, which determine the port position as the hub one (Aversa et al. 2005). The use of MCDM (Multi Criteria Decision Making) has also been promoted in the analysis of container port competitiveness. Song and Yeo (2004) carried out the competitive analysis of Chinese container ports using AHP (Analytic Hierarchy Process), while Guy and Urli (2006) used multi-criteria analysis to examine port selection in case of Montreal-New York ports. The AHP method has found an application in transshipment port selection from a global perspective (Lirn et al. 2004). The quantitative simulation modeling of some intelligent port transport systems' functional characteristics have been done by Jolić (2003) and Jolić et al. (2004). Also, some quantitative analyses of the relevant indicators of the traffic flows (including some ports' flows), as well as their structure and dynamics have been presented in the work of Poletan-Jugović et al. (2009). Data Envelopment Analysis (DEA) is the method usually applied (Tongzon 2001; Barros 2003; Barros, Athanassiou 2004; Cullinane et al. 2006), though some authors (Panayides et al. 2009) critically reviewed its application in seaport economic efficiency measurement. Container port competition has also been considered in the context of applying hierarchical fuzzy processes (Huang et al. 2003; Yeo, Song 2006). All variables that are taken into consideration in these works are mostly related to infrastructure and superstructure, financial and development parameters, productivity and efficiency. They are also measurable and comparable, and discussions based on these variables are essentially objective.

In the case of ports investigated in this article which are characterized by the unique attribute of pretending to share the same target market, in the most general sense, their marketing positioning is the activity of designing a port offer and its image in terms of taking a distinctively (recognizable) place in the mind of the target market (customers), aiming to increase potential benefits for the ports (Kotler, Keller 2008). Previous researches have rarely, and mostly in the widest economic context and less in the marketing one, discussed the question of the seaport positioning strategy development. Not earlier than in the 90's of the previous century, the strategic positioning of seaports started to be discussed from the point of seaport economy, i.e. port position in terms of growth, market participation and diversification, at the same time including the aspects of added value (Haezendonck et al. 2000). Although the subject of seaport positioning hasn't been sufficiently researched in terms of customers' preferences, some elements featuring the marketing differentiation strategy had already been determined by the 80 's of the previous century (Slack 1985). These researches aimed to find factors that would make the seaport services different and recognizable, e.g. based on efficiency, quality, reliability, etc. There are, of course, many contemporary research works that descriptively present current trends in container ports and shipping business. Notteboom and Rodrigue (2005) introduce the term of the port regionalization. Slack (2007) describes the terminalization of seaports. Particularly relevant topics are shipping networks and port development (Comtois, Slack 2007; Heaver et al. 2000). A very attractive area of research is the domain of maritime supply chains and the role of ports in them (Notteboom, Winkelmans 2001; Carbone, De Martino 2003; Bichou, Gray 2004; Carbone, Gouvernal 2007; Wang, Cullinane 2006; Panayides, Song 2009).

All the mentioned methodologies confirm the extent and complexity of topics related to the container ports positioning strategy. What is the most important in this paper and what makes it original in a way, is that the particular attention has been paid to the marketing dimension of the issue. This means that all factors that are considered here, both quantitative and qualitative, are to be chosen by their importance regarding users' satisfaction, which is essential for ports marketing positioning.

\section{Methodology}

The applied methodology can be divided into two categories:

- firstly, the quantitative method that includes PROMETHEE (Preference Ranking Organization Method for Enrichment Evaluations) multicriteria decision making method;

- secondly, the multi-criteria procedure of the Analytic Hierarchy Process (AHP).

In order to account different criteria, we developed four survey campaigns aimed at the following groups:

- the port community members;

- port development and marketing managers;

- port customers and academic researchers.

Additionally, in order to position the considered eight seaports:

P1 - Bar;

P2 - Durres;

P3 - Constantza;

P4 - Koper;

P5 - Piraeus;

P6 - Ploce;

P7 - Rijeka;

P8 - Thessaloniki, 
the two sets of criteria have been identified and analyzed:

- quantitative (A);

- qualitative (B).

These criteria are divided into the appropriate subcriteria sets as it is given in Tables 1-6. Regarding the first set of the quantitative criteria exact numerical values (A), the PROMETHEE multi-criteria decision making method was employed and the appropriate ranks were obtained for each sub-criteria set. In the second set of the qualitative criteria (B), each criterion was qualified by the linguistic value (YES/NO), and subsequently translated into the appropriate binary value (0/1): zero NO, one - YES. Then, these $(0 / 1)$ values were summed separately per each sub-criteria set previously identified within complete B set of criteria. These sums were finally pondered by the average weight coefficients being estimated on the basis of AHP method, and the total score was found as the average value of all previously calculated and pondered sums per each sub-criterion set in $\mathrm{B}$.

\section{Quantitative Criteria Analysis and Obtained Results}

The PROMETHEE is one of the most efficient multi-criteria methods, based on the numerous research works, among which are those of Brans et al. (1985, 1986), Petrović et al. (1988), etc. Namely, the preference function and the weights given to each variable have to be chosen before it might be applied to any problem. This method has been applied in many research articles in the field of seaport management, because it is reliable, the outcomes are easy for interpreting economically, and in marketing manner (Castillo-Manzano et al. 2009). In this article, PROMETHEE is applied to the problem of ranking (positioning) a finite number of alternative ports. Since the relative importance of the considered criteria is usually not the same, it is necessary to estimate their importance by giving them weight coefficients. In order to reduce the subjectivity factor in estimating these coefficients and setting preference function types, we have conducted a survey among the focus group experts. The quantitative set of criteria (A) is composed of the following sub-criteria sets:

A1 - container terminal infrastructure features;

A2 - cargo handling vertical and horizontal mechanization;

A3 - cargo handling turnover and human capacities, along with the corresponding units given in Table 1 . Each of the used criteria represents one of the aspects of the investigated seaports' competitiveness. When deciding about these criteria and sub-criteria choices, we used the studies criteria by Rugman and Verbeke (1993), Pardali and Michalopoulos (2008), Tongzon and Heng (2005), Yeo et al. (2008).

After setting the general scheme of the quantitative criteria given in Table 1, the exact numerical data values were acquired by the authors' survey of the respective ports in cooperation with the ports managers. These numerical data are given in Table 2 .
Table 1. Quantitative criteria

\begin{tabular}{|c|c|c|c|}
\hline \multirow{16}{*}{ 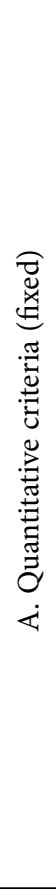 } & \multirow{6}{*}{$\begin{array}{l}\text { A1. Container } \\
\text { terminal } \\
\text { infrastructure } \\
\text { features }\end{array}$} & C_A1.1 & $\begin{array}{l}\text { Number of container } \\
\text { terminals (no.) }\end{array}$ \\
\hline & & C_A 1.2 & Number of berths (no.) \\
\hline & & C_A1.3 & Total length of berths (m) \\
\hline & & C_A1.4 & Maximum water depth $(\mathrm{m})$ \\
\hline & & C_A1.5 & $\begin{array}{l}\text { Terminal storage capacity } \\
\text { (TEU) }\end{array}$ \\
\hline & & C_A1.6 & Number of reefer plugs (no.) \\
\hline & \multirow{6}{*}{$\begin{array}{l}\text { A2. Cargo } \\
\text { handling: } \\
\text { vertical and } \\
\text { horizontal } \\
\text { mechanization }\end{array}$} & C_A2.1 & Gantry crane (no.) \\
\hline & & C_A2.2 & Transfer crane (no.) \\
\hline & & C_A2.3 & Straddle carrier (no.) \\
\hline & & C_A2.4 & Forklift (no.) \\
\hline & & C_A2.5 & Reach stacker (no.) \\
\hline & & C_A2.6 & Container trailer (no.) \\
\hline & \multirow{4}{*}{$\begin{array}{l}\text { A3. Cargo } \\
\text { handling } \\
\text { turnover } \\
\text { and human } \\
\text { capacities }\end{array}$} & C_A3.1 & $\begin{array}{l}\text { Total cargo handling } \\
\text { turnover (tons) }\end{array}$ \\
\hline & & C_A3.2 & Annual operations (days) \\
\hline & & C_A3.3 & Daily operations (hours) \\
\hline & & C_A3.4 & Number of employees (no.) \\
\hline
\end{tabular}

Upon the numerical data (Table 2), PROMETHEE multi-criteria decision making method has been employed and the obtained results for positive $(\mathrm{Phi+})$ and negative $(P h i-)$ flows, along with the net preference flow (Phi), are given in Tables 3-5. This has been done for each sub-criteria sets (A1, A2, and A3) composing quantitative criteria (A). The weight coefficients, as well as preference function type (linear), and the corresponding coefficients (here, $q$ and $p$ ) were estimated through the consultations of the focus group experts (the port managers and experienced academic researchers).

Thus, the obtained results are as follows:

a) The complete rank of the considered ports, obtained by the PROMETHEE II method (PROMCALC software), for the first sub-criteria set (A1) is:

1. Constantza;

2. Koper;

3. Piraeus;

4. Thessaloniki;

5. Rijeka;

6. Durres;

7. Bar;

8. Ploce (Table 3);

b) The complete rank of the considered ports, obtained by PROMETHEE II method (PROMCALC software) for the second sub-criteria set (A2) is:

1. Constantza;

2. Koper;

3. Piraeus;

4. Thessaloniki;

5. Rijeka;

6. Durres;

7. Ploce;

8. Bar (Table 4); 
Table 2. Quantitative criteria (A): sub-criteria sets A1, A2, and A3

\begin{tabular}{ccccccccc}
\hline Criteria/Port & P1 & P2 & P3 & P4 & P5 & P6 & P7 & P8 \\
\hline C_A1.1 & 1 & 1 & 3 & 1 & 2 & 1 & 1 & 1 \\
\hline C_A1.2 & 2 & 11 & 9 & 25 & 9 & 1 & 2 & 2 \\
\hline C_A1.3 & 330 & 2200 & 1968 & 3200 & 2774 & 280 & 450 & 550 \\
\hline C_A1.4 & 14 & 11.5 & 16.5 & 18 & 18 & 13.8 & 12 & 12 \\
\hline C_A1.5 & 1760 & 2000 & 35472 & 24400 & 30500 & 1400 & 6500 & 7390 \\
\hline C_A1.6 & 174 & 105 & 987 & 340 & 288 & 32 & 150 & 276 \\
\hline C_A2.1 & 1 & 1 & 8 & 8 & 7 & 1 & 3 & 4 \\
\hline C_A2.2 & 0 & 2 & 15 & 14 & 1 & 0 & 0 & 0 \\
\hline C_A2.3 & 0 & 0 & 0 & 0 & 10 & 0 & 1 & 17 \\
\hline C_A2.4 & 2 & 2 & 7 & 0 & 3 & 1 & 0 & 6 \\
\hline C_A2.5 & 0 & 4 & 4 & 45 & 1 & 3 & 9 & 5 \\
\hline C_A2.6 & 2 & 5 & 60 & 30 & 2 & 5 & 14 & 1 \\
\hline C_A3.1 & 2407.4 & 968.3 & 36975.6 & 15372.0 & 11706.2 & 4532.8 & 4611.7 & 2281.4 \\
\hline C_A3.2 & 361 & 365 & 364 & 365 & 362 & 365 & 365 & 365 \\
\hline C_A3.3 & 24 & 24 & 24 & 24 & 24 & 24 & 24 & 24 \\
\hline C_A3.4 & 65 & 92 & 546 & 130 & 1250 & 15 & 83 & 150 \\
\hline
\end{tabular}

Table 3. PROMETHE II complete rank of the ports for A1 sub-criteria set

\begin{tabular}{|c|c|c|c|c|c|c|c|c|c|c|}
\hline Criteria & C_A1.1 & C_A1.2 & C_A1.3 & C_A1.4 & C_A1.5 & C_A1.6 & & & & \\
\hline $\max / \min$ & $\max$ & $\max$ & $\max$ & $\max$ & $\max$ & $\max$ & Phi+ & Phi- & $P h i$ & Rank \\
\hline Port/weight & 0.15 & 0.10 & 0.15 & 0.15 & 0.35 & 0.10 & & & & \\
\hline P1 & 1 & 2 & 330 & 14 & 1760 & 174 & 0.037 & 0.402 & -0.365 & 7 \\
\hline P2 & 1 & 11 & 2200 & 11.5 & 2000 & 105 & 0.740 & 0.382 & -0.300 & 6 \\
\hline P3 & 3 & 9 & 1968 & 16.5 & 35472 & 987 & 0.628 & 0.027 & 0.601 & 1 \\
\hline P4 & 1 & 25 & 3200 & 18 & 24400 & 340 & 0.689 & 0.117 & 0.472 & 2 \\
\hline P5 & 2 & 9 & 2774 & 18 & 30500 & 288 & 0.531 & 0.059 & 0.471 & 3 \\
\hline P6 & 1 & 1 & 280 & 13 & 1400 & 32 & 0.016 & 0.454 & -0.439 & 8 \\
\hline P7 & 1 & 2 & 450 & 12 & 6500 & 150 & 0.102 & 0.368 & -0.266 & 5 \\
\hline P8 & 1 & 2 & 550 & 12 & 7390 & 276 & 0.162 & 0.330 & -0.168 & 4 \\
\hline Preference & linear & linear & linear & linear & linear & linear & & & & \\
\hline$q$ & 1 & 1 & 300 & 1 & 1500 & 30 & & & & \\
\hline$p$ & 3 & 24 & 3000 & 5 & 7000 & 150 & & & & \\
\hline
\end{tabular}

Table 4. PROMETHE II complete rank of the ports for A2 sub-criteria set

\begin{tabular}{|c|c|c|c|c|c|c|c|c|c|c|}
\hline Criteria & C_A2.1 & C_A2.2 & C_A2.3 & C_A2.4 & C_A2.5 & C_A2.6 & & & & \\
\hline $\max / \min$ & $\max$ & $\max$ & $\max$ & $\max$ & $\max$ & $\max$ & Phi+ & Phi- & $P h i$ & Rank \\
\hline Port/weight & 0.40 & 0.20 & 0.10 & 0.10 & 0.10 & 0.10 & & & & \\
\hline P1 & 1 & 0 & 0 & 2 & 0 & 2 & 0.007 & 0.438 & -0.431 & 8 \\
\hline $\mathrm{P} 2$ & 1 & 2 & 0 & 2 & 4 & 5 & 0.045 & 0.385 & -0.340 & 6 \\
\hline P3 & 8 & 15 & 0 & 7 & 4 & 60 & 0.643 & 0.052 & 0.591 & 1 \\
\hline P4 & 8 & 14 & 0 & 0 & 45 & 30 & 0.629 & 0.081 & 0.548 & 2 \\
\hline P5 & 7 & 1 & 10 & 3 & 1 & 2 & 0.315 & 0.182 & 0.139 & 3 \\
\hline P6 & 1 & 0 & 0 & 1 & 3 & 5 & 0.018 & 0.399 & -0.381 & 7 \\
\hline P7 & 3 & 0 & 1 & 0 & 9 & 14 & 0.176 & 0.326 & -0.150 & 5 \\
\hline P8 & 4 & 0 & 17 & 6 & 5 & 1 & 0.278 & 0.247 & 0.031 & 4 \\
\hline
\end{tabular}

\begin{tabular}{ccccccc}
\hline Preference & linear & linear & linear & linear & linear & linear \\
\hline$q$ & 1 & 1 & 1 & 1 & 1 & 1 \\
\hline$p$ & 5 & 10 & 15 & 5 & 5 & 15 \\
\hline
\end{tabular}


Table 5. PROMETHE II complete rank of the ports for A3 sub-criteria set

\begin{tabular}{|c|c|c|c|c|c|c|c|c|}
\hline Criteria & C_A3.1 & C_A3.2 & C_A3.3 & C_A3.4 & & & & \\
\hline $\max / \min$ & $\max$ & $\max$ & $\max$ & $\min$ & Phi+ & Phi- & Phi & Rank \\
\hline Port/weight & 0.50 & 0.20 & 0.20 & 0.10 & & & & \\
\hline $\mathrm{P} 1$ & 2407.4 & 361 & 24 & 65 & 0.024 & 0.220 & -0.196 & 6 \\
\hline P2 & 968.3 & 365 & 24 & 92 & 0.020 & 0.257 & -0.238 & 8 \\
\hline P3 & 36975.6 & 364 & 24 & 546 & 0.510 & 0.034 & -0.476 & 1 \\
\hline $\mathrm{P} 4$ & 15372.0 & 365 & 24 & 130 & 0.393 & 0.072 & 0.322 & 2 \\
\hline P5 & 11706.2 & 362 & 24 & 1250 & 0.277 & 0.186 & 0.091 & 3 \\
\hline P6 & 4532.8 & 365 & 24 & 15 & 0.059 & 0.186 & -0.127 & 5 \\
\hline P7 & 4611.7 & 365 & 24 & 83 & 0.59 & 0.185 & -0.126 & 4 \\
\hline P8 & 2281.4 & 365 & 24 & 150 & 0.022 & 0.223 & -0.201 & 7 \\
\hline Preference & linear & linear & linear & linear & & & & \\
\hline$q$ & 900 & 360 & 16 & 100 & & & & \\
\hline$p$ & 11000 & 365 & 24 & 1000 & & & & \\
\hline
\end{tabular}

c) The complete rank of the considered ports, obtained by PROMETHEE II method (PROMCALC software), for the first sub-criteria set (A3) is:

1. Constantza;

2. Koper;

3. Piraeus;

4. Rijeka;

5. Ploce;

6. Bar;

7. Thessaloniki;

8. Durres (Table 5).

The numerical results of sea ports positioning by the PROMETHEE MCDM method for three different sub-criteria sets (A1, A2, and A3) regarding the quantitative criteria overall set A are graphically shown below in Figs 1-3, as well.

According to the group of A1 sub-criteria (container terminal infrastructure features), Constantza is the leading port, which is realistic, due to the fact that this port has the largest number of container terminals, terminal storage capacity, and number of reefer plugs. Also, the remaining three of the A1 sub-criteria are very competitive to other ports' sub-criteria. Koper port occupies the second position, which can also be confirmed, since this port has the largest number of berths and consequently the greatest length of berths, which can be an extremely important parameter for shipping companies choosing this port, if it is compared to the rest of the competing ports. Also, this port has the highest value of the maximum water depth that could be a crucial port choice criterion for modern mega-carriers. Piraeus port is in the third position that is particularly determined by a significant number of reefer plugs and very competitive surface of storage capacity. This port also has a significant potential in terms of the number of container terminals. Thessaloniki port occupies a position which is very close to an imaginary average port (Fig. 1). The remaining ports, in terms of $\mathrm{A} 1$ sub-criteria set, show a smaller degree of competitiveness compared to the four above mentioned well positioned ports.

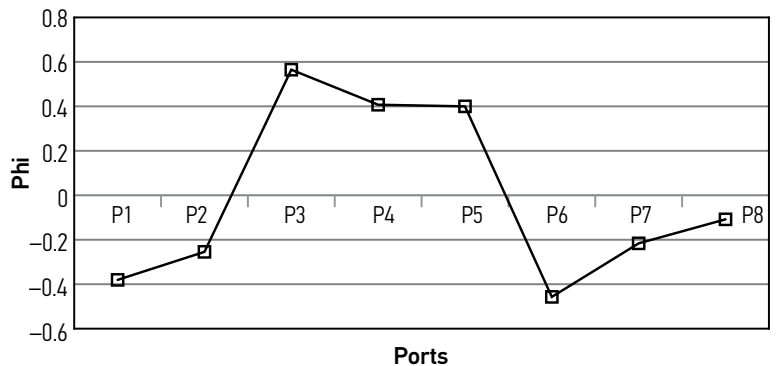

Fig. 1. The ports positions corresponding to the PROMETHEE net flows determined according to the A1 set sub-criteria values

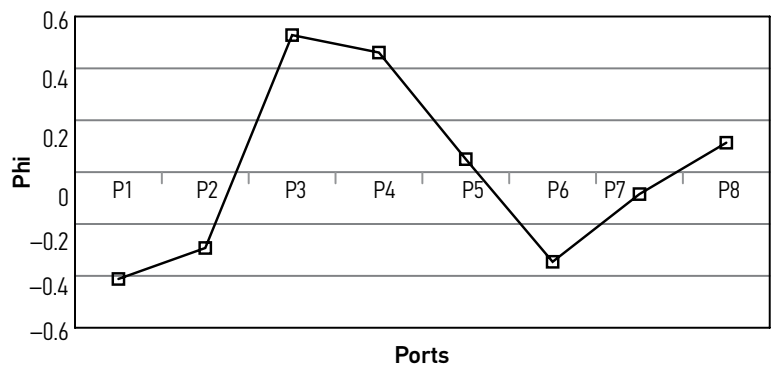

Fig. 2. The ports positions corresponding to the PROMETHEE net flows determined according to the A2 set sub-criteria values

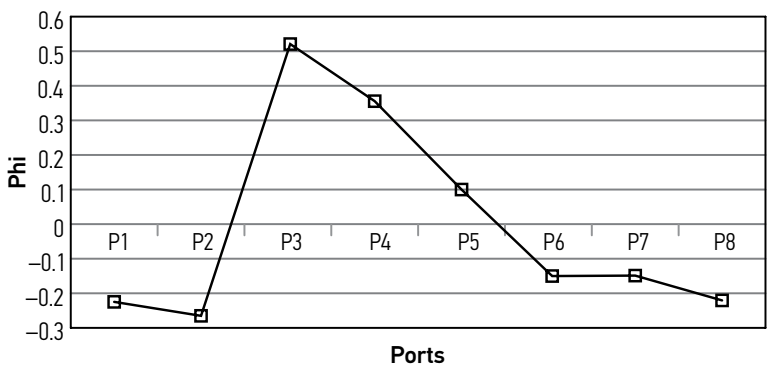

Fig. 3. The ports' positions corresponding to the PROMETHEE net flows determined according to the A3 set sub-criteria values 
According to the group of A2 sub-criteria set (cargo handling: vertical and horizontal mechanization), Constantza port occupies the leadership position as in the previous case. This time, Koper port is very close to Constantza, while they share the same number of gantry cranes. Also, these two ports have small differences related to horizontal mechanization, however, slight advantage belongs to Constantza port. The remaining ports are of nearly similar ranking as they are ranked in the case of A1 sub-criteria set. Special emphasis is given to the Thessaloniki port, which now occupies the fourth place, and its position is very close to the third positioned Pireaus port. Bar port is in this case in the last position, which can be a very significant signal to this port's technical and development department to improve and modernize this segment of its operation.

According to the group A3 sub-criteria (cargo handling turnover and human capacities), Constantza is highly advanced in comparison with all remaining ports, which confirms the highest total cargo throughput. This port has almost twice higher cargo handling turnover than the second ranked Koper port, and almost three times higher than the third positioned Piraeus port. According to this criterion, Durres port indicates smaller degree of competitiveness, which means that the marketing and development department of this port must intensify efforts in increasing the volume of traffic in this port, particularly container traffic. Concerning human capacity, Piraeus port has the largest number of employees, while each of the analyzed ports operate 24 hours a day, though this criterion in fact has no impact of the ports' positions. Concerning different values of the weight coefficients, different types of preference functions and their characteristic coefficients - ports' positions should be slightly, or even considerably different. Thus, in the next sub-sections, additional method based on both qualitative and quantitative estimations have been used in determining the ports' mutual positions as an additional aid for the ports' (eventual) (re)positioning.

\section{Qualitative Criteria Analysis and Obtained Results}

The container ports are likely to be more competitive if they are superior in terms of: proximity to key centers of production and consumption, and major trade lanes; maritime excellence and hinterland access; levels of productivity; efficiency of the capacity management; the ability to adapt to the new logistics business environment; potential to attract private capital at the level of terminal operations; possibility to become the key drivers of the local economies, and being supported by the stakeholders in the port area and the wider community (Noteboom, Yap 2012). Accordingly, the second qualitative set of criteria (B) is composed of the following sub-criteria sets:

B1 - infra and superstructure features;

B2 - connections with hinterland;

B3 - marketing features;

B4 - port management models;

B5 - vessels' and cargos' services;

B6 - Information and Communication Technology (ICT) applications.
Table 6. Qualitative criteria

\begin{tabular}{|c|c|c|c|}
\hline & \multirow{6}{*}{$\begin{array}{l}\text { B1. Infra and } \\
\text { superstructure } \\
\text { features }\end{array}$} & C_B1.1 & Container terminal $(\mathrm{Y} / \mathrm{N})$ \\
\hline & & C_B1.2 & $\begin{array}{l}\text { General cargo terminal } \\
(\mathrm{Y} / \mathrm{N})\end{array}$ \\
\hline \multirow{32}{*}{ 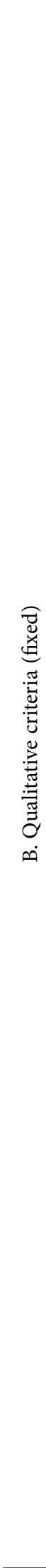 } & & C_B1.3 & $\begin{array}{l}\text { Bulk cargo terminal } \\
(\mathrm{Y} / \mathrm{N})\end{array}$ \\
\hline & & C_B1.4 & $\begin{array}{l}\text { Liquid cargo terminal } \\
(\mathrm{Y} / \mathrm{N})\end{array}$ \\
\hline & & C_B1.5 & Ro-Ro terminal $(\mathrm{Y} / \mathrm{N})$ \\
\hline & & C_B1.6 & Passenger terminal $(\mathrm{Y} / \mathrm{N})$ \\
\hline & & C_B2.1 & $\begin{array}{l}\text { Railway connections } \\
(\mathrm{Y} / \mathrm{N})\end{array}$ \\
\hline & & C_B2.2 & Road connections $(\mathrm{Y} / \mathrm{N})$ \\
\hline & $\begin{array}{l}\text { B2. Connections } \\
\text { with hinterland }\end{array}$ & C_B2.3 & $\begin{array}{l}\text { Pipelines connections } \\
(\mathrm{Y} / \mathrm{N})\end{array}$ \\
\hline & & C_B2.4 & Barge service $(\mathrm{Y} / \mathrm{N})$ \\
\hline & & C_B2.5 & Shuttle service $(\mathrm{Y} / \mathrm{N})$ \\
\hline & & C_B2.6 & Bottleneck $(\mathrm{Y} / \mathrm{N})$ \\
\hline & & C_B3.1 & Free zone $(\mathrm{Y} / \mathrm{N})$ \\
\hline & & C_B3.2 & $\begin{array}{l}\text { Value-added logistics } \\
\text { services }(\mathrm{Y} / \mathrm{N})\end{array}$ \\
\hline & $\begin{array}{l}\text { B3. Marketing } \\
\text { features }\end{array}$ & C_B3.3 & $\begin{array}{l}\text { Distribution centers } \\
(\mathrm{Y} / \mathrm{N})\end{array}$ \\
\hline & & C_B3.4 & $\begin{array}{l}\text { Quality Management } \\
\text { System }(\mathrm{Y} / \mathrm{N})\end{array}$ \\
\hline & & C_B3.5 & $\begin{array}{l}\text { Integrated marketing } \\
\text { communications }(\mathrm{Y} / \mathrm{N})\end{array}$ \\
\hline & & C_B4.1 & Service port model $(\mathrm{Y} / \mathrm{N})$ \\
\hline & B4. Port & C_B4.2 & Tool port model $(\mathrm{Y} / \mathrm{N})$ \\
\hline & models & C_B4.3 & $\begin{array}{l}\text { Landlord port model } \\
(\mathrm{Y} / \mathrm{N})\end{array}$ \\
\hline & & C_B4.4 & Private port model $(\mathrm{Y} / \mathrm{N})$ \\
\hline & & C_B5.1 & Vessel monitoring $(\mathrm{Y} / \mathrm{N})$ \\
\hline & & C_B5.2 & Vessel repair $(\mathrm{Y} / \mathrm{N})$ \\
\hline & & C_B5.3 & Vessel servicing $(\mathrm{Y} / \mathrm{N})$ \\
\hline & & C_B5.4 & Container control $(\mathrm{Y} / \mathrm{N})$ \\
\hline & $\begin{array}{l}\text { B5. Vessels' and } \\
\text { cargos' services }\end{array}$ & C_B5.5 & $\begin{array}{l}\text { Non-containerized cargo } \\
\text { control }(\mathrm{Y} / \mathrm{N})\end{array}$ \\
\hline & & C_B5.6 & $\begin{array}{l}\text { Automatic scheduling } \\
\text { and stacking of containers } \\
(\mathrm{Y} / \mathrm{N})\end{array}$ \\
\hline & & C_B5.7 & $\begin{array}{l}\text { Automatic monitoring } \\
\text { of cargo in stock }(\mathrm{Y} / \mathrm{N})\end{array}$ \\
\hline & & C_B5.8 & Container leasing $(\mathrm{Y} / \mathrm{N})$ \\
\hline & & C_B6.1 & $\begin{array}{l}\text { The classic ICT system } \\
(\mathrm{Y} / \mathrm{N})\end{array}$ \\
\hline & & C_B6.2 & $\begin{array}{l}\text { ERP (Enterprise Resource } \\
\text { Planning) }(\mathrm{Y} / \mathrm{N})\end{array}$ \\
\hline & $\begin{array}{l}\text { B6. ICT } \\
\text { applications }\end{array}$ & C_B6.3 & $\begin{array}{l}\text { (EDI) Electronic } \\
\text { data interchange } \\
\text { service }(\mathrm{Y} / \mathrm{N})\end{array}$ \\
\hline & & C_B6.4 & $\begin{array}{l}\text { MIS (Management } \\
\text { Information System) } \\
(\mathrm{Y} / \mathrm{N})\end{array}$ \\
\hline & & C_B6.5 & $\begin{array}{l}\text { (VTS) Vessel traffic } \\
\text { service service }(\mathrm{Y} / \mathrm{N})\end{array}$ \\
\hline
\end{tabular}


These criteria are listed in Table 6, along with the corresponding sub-criteria sets. Since the values of the qualitative criteria are expressed in terms of zero-one numerical values, these values are summarized per each sub-criteria sets in $B$, and then pondered by the average weight coefficients previously estimated by the AHP method, explained in more detail in the following subsections of the paper.

\subsection{Ranking Qualitative Sub-Criteria Sets}

The idea of qualitative sub-criteria sets' ranking is associated with AHP (Saaty 1977, 1994a, 1994b, 2003) approach applied to sub-criteria sets of B qualitative complete criteria set, with respect to the estimates of the respondents. Namely, ranking is a procedure, where the most significant sub-criteria set is given the highest rank, the last significant sub-criteria set is given the lowest rank, while the other sub-criteria sets are somewhere in between these two upper and down rank boundary values. Here, the respondents, i.e. three competent persons (managers and/or administrative staff members), per each of the considered ports, are asked to compare each pair of the criteria sets (B1...B6) according to the Saaty scale by using grades:

1 - same importance;

3 - weakly more importance;

5 - moderately more importance;

7 - strongly more importance;

9 - absolutely more importance of the first than the second considered criterion,

or, by the corresponding reciprocity values depending on the mutual importance of the compared elements composing the certain pair(s). Although 24 competent persons were asked to create the Saaty matrixes, only ten Saaty matrixes have been taken into further consideration. Namely, the application of AHP requires highly developed logical thinking, though the estimate of only one highly qualified expert may be more important than the estimates made by a number of inexperienced persons (Sivilevičius, Maskeliūnaitè 2010). By the normalized eigenvector values calculus (Shikin, Chhartishvili 2002), the ranks of the considered criteria B1...B6 have been calculated (Table 7), along with the values of the largest eigenvalue $\left(\lambda_{\max }\right)$, and the consistency index (CI), while the random index (RI) is equal to 1.24 in all cases, since the number of criteria is constant and equal to six. It is obvious that all $\lambda_{\max }$ values, for each considered matrix, are less than 0.01 , which is to be fulfilled in order to provide a satisfying degree of the Saaty matrix consistency (Table 8).

Though, the results of the sub-criteria sets weights $\left(w_{i}, i=\overline{1,6}\right)$ in $\mathrm{B}$, and corresponding ranks, per each of the ten considered Saaty's matrixes obtained by the algorithm presented in details in the article of Sivilevičius and Maskeliunaite (2010) are given in Table 7. The values of the largest eigenvalue $\left(\lambda_{\max }\right)$, and the ratio of consistency (CR) are given in Table 8 per each respondent, as it is previously noted above. Used Mathematica codes are given in Table 9.

The values obtained by this code (for respondent R2) are: $\lambda=6.527, C I=0.105, R I=1.24, C R=0.085$. Since, $C R \leq 0.1$ it means that the considered Saaty's matrix is a consistent one. On the basis of the ranks of $\mathrm{B} 1 \ldots \mathrm{B} 6$ sub-criteria sets in $\mathrm{B}$, the average weights per each sub-criteria set have been calculated and used for pondering the sums of $0 / 1$ values corresponding to each criteria in $\mathrm{B} 1$... B6 sub-criteria sets. The values $0 / 1$ for all analyzed criteria $B$ had been previously collected at the

Table 7. The ranks of the sub-criteria sets in B assigned by ten competitive respondents

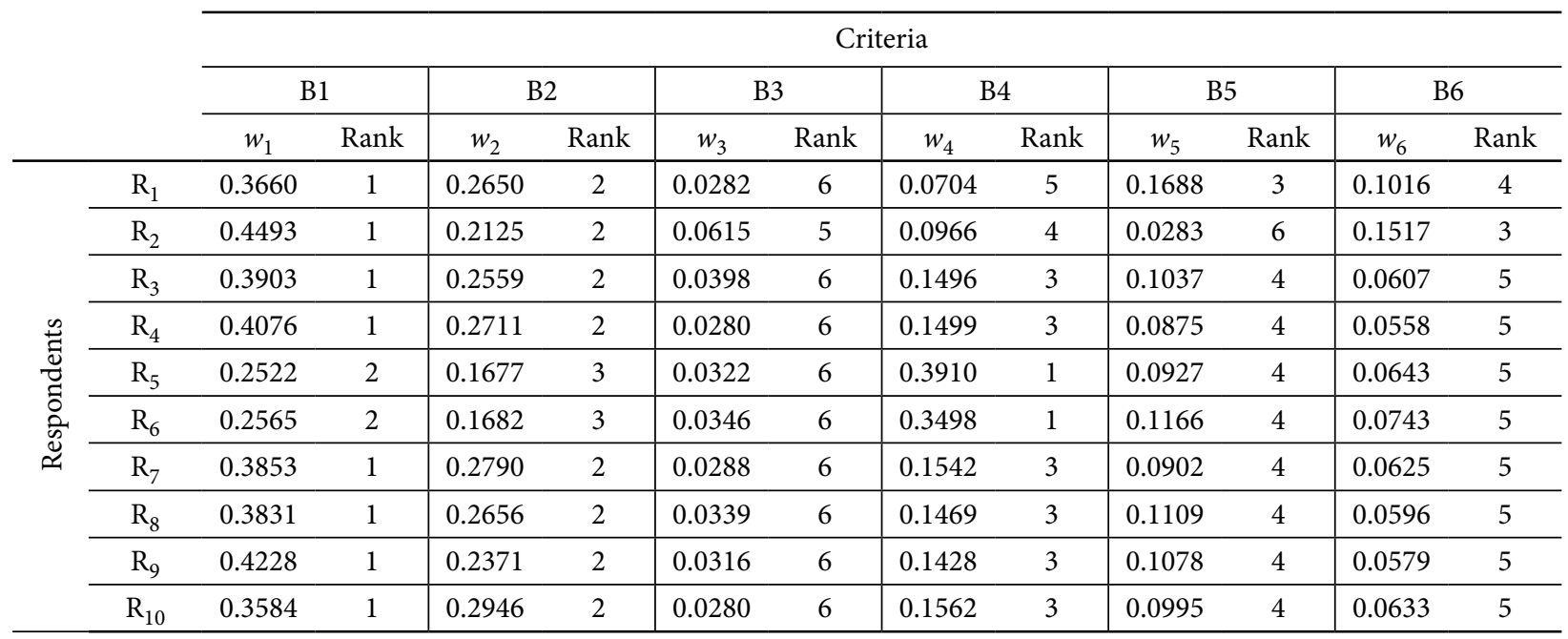

Table 8. The largest eigenvalue and ratio of consistency per each AHP matrix given by the respondents

\begin{tabular}{ccccccccccc}
\hline & $\mathrm{R} 1$ & $\mathrm{R} 2$ & $\mathrm{R} 3$ & $\mathrm{R} 4$ & $\mathrm{R} 5$ & $\mathrm{R} 6$ & $\mathrm{R} 7$ & $\mathrm{R} 8$ & $\mathrm{R} 9$ & $\mathrm{R} 10$ \\
\hline$\lambda_{\max }$ & 6.5620 & 6.5274 & 6.4419 & 6.4441 & 6.5202 & 6.5758 & 6.5439 & 6.4711 & 6.5972 & 6.5278 \\
\hline $\mathrm{CR}$ & 0.0906 & 0.0851 & 0.0713 & 0.0888 & 0.0839 & 0.0929 & 0.0877 & 0.0760 & 0.0963 & 0.0851 \\
\hline
\end{tabular}


Table 9. Code 1: calculating weight coefficients and testing Saaty's matrix consistency

Code 1: Off[General::spell1]

( ${ }^{*} \mathrm{n}=$ Input [“Number of criteria is (n):”]; $)$

$\left({ }^{\star} \mathrm{A}=\right.$ Table $[0,\{\mathrm{n}\},\{\mathrm{n}\}]$; For $[\mathrm{i}=1, \mathrm{i} \leq \mathrm{n}, \mathrm{i}++$, For $[\mathrm{j}=1, \mathrm{j} \leq \mathrm{n}, \mathrm{j}++, \mathrm{A}[[\mathrm{i}, \mathrm{j}]]=$ Input [“Input Saaty matrix A [“ $<>$ ToString $[\mathrm{i}]<>$

"’” $<>$ ToString[i] $<>$ "]:”]; If $[\mathrm{A}=[[\mathrm{i}, \mathrm{j}]]==\$$ Canceled $\vee \mathrm{A}[[\mathrm{i}, \mathrm{j}]]==$ Null, Abort []$]]] ; *)$

$\mathrm{n}=6 ; \mathrm{A}=\{\{1,5,9,3,5,5\},\{1 / 5,1,7,3,3,3\},\{1 / 9,1 / 7,1,1 / 5,1 / 5,1 / 3\},\{1 / 3,1 / 3,5,1,3,3\},\{1 / 5,1 / 3,5,1 / 3,1,3\},\{1 / 5,1 / 3,3,1 / 3,1 / 3,1\}\} ;$

$\mathrm{wn}=\operatorname{Table}[0,\{\mathrm{n}\}] ; \mathrm{wp}=\operatorname{Table}[0,\{\mathrm{n}\}] ; \operatorname{For}\left[\mathrm{i}=1 ; \mathrm{ws}=0, \mathrm{i} \leq \mathrm{n}, \mathrm{i}++, \mathrm{wn}[[\mathrm{i}]]=\prod_{j=1}^{n} A[[i, j]] ; \mathrm{wp}[[\mathrm{i}]]=\mathrm{wn}[[\mathrm{i}]] \wedge(1 / \mathrm{n}) ; \mathrm{ws}=\mathrm{ws}+\mathrm{wp}[[\mathrm{i}]]\right] ;$
$\mathrm{w}=\operatorname{Table}[0,\{\mathrm{n}\},\{1\}] ;$ For $[\mathrm{i}=1 ; \mathrm{i} \leq \mathrm{n}, \mathrm{i}++, \mathrm{wn}[[\mathrm{i}, 1]]=\mathrm{wp}[[\mathrm{i}]] / \mathrm{ws}]$

$\mathrm{V}=\mathrm{A} \cdot \mathrm{w} ; \mathrm{l}=\mathrm{V} / \mathrm{w} ; \lambda=\frac{1}{n} \sum_{i=1}^{n} l[[i, 1]] ; \mathrm{CI}=(\lambda-\mathrm{n}) /(\mathrm{n}-1) ; \mathrm{RI}=\{0,0,0.58,0.9,1.12,1.24,1.32,1.41,1.45\} ; \mathrm{CR}=\mathrm{CI} / \mathrm{RI}[[\mathrm{n}]]$;

Print ["Eigen value: $\lambda=$ ",N[$\lambda]$ ]; Print ["Index of Saaty's scale consistency is: $\mathrm{CI}=$ ", $N[C I]$;

Print ["Random index of consistency is: $\mathrm{RI}=$ ", N[RI]]; Print ["Ratio of consistency indexes is: $\mathrm{CR}=$ ", N[CR]]; If CR $\leq 0.1$,

Print [“Saaty's matrix is consistant"], Print [“Saaty's matrix is not consistant"]

considered ports. The total score per each analyzed port was calculated by the formulae:

$$
\begin{aligned}
& B_{S C R_{i}}=\sum_{j=1}^{6} v(i, j) \cdot \bar{w}_{1 n}+ \\
& \sum_{k=1}^{6} v(i, k) \cdot \bar{w}_{2 n}+\sum_{l=1}^{5} v(i, l) \cdot \bar{w}_{3 n}+ \\
& \sum_{m=1}^{4} v(i, m) \cdot \bar{w}_{4 n}+\sum_{n=1}^{8} v(i, n) \cdot \bar{w}_{5 n}+ \\
& \sum_{p=1}^{5} v(i, p) \cdot \bar{w}_{6 n} ; i=\overline{1,8}_{1,}
\end{aligned}
$$

where: $B_{S C R_{i}}$ - is total score for the $i$-th considered port, while $i=\overline{1,8}$ and corresponds to the analyzed ports; $v(i, j), v(i, k), v(i, l), v(i, m), v(i, n), v(i, p)$ - are the variables' binary values 0 , or 1 for $i$-th port, while $j=\overline{1,6}, k=\overline{1,6}, l=\overline{1,5}, \quad m=\overline{1,4}, n=\overline{1,8}, \quad p=\overline{1,5}$ are indexes of the criteria within each sub-criteria sets in $B$ set; $\bar{w}_{1 n} \ldots \bar{w}_{6 n}-$ are the normalized average values of the weight coefficients for each B1...B6 subsets of criteria in $\mathrm{B}$. The positions of the analyzed ports obtained by the calculations (1) are shown in Fig. 4.

However, the method by which the normalized average weight coefficients per each sub-criterion set in $B$ has been determined, needs to be explained, as well. The idea of evaluating these weight coefficients is associated with the sum of ranks of each criterion $c_{q}$, with respect to the estimates of respondents:

$$
c_{q}=\sum_{r=1}^{10} c_{q r} ; q=\overline{1,6},
$$

where: $c_{q}$ - is the sum of ranks of each criterion set (B1...B6), while $\mathrm{q}$ is the number of sub-criterion sets in $B$ (here 6), and $\mathrm{r}$ is number of experts, or respondents (here 10); $c_{q r}$-is rank of the $q$-th criterion estimated by the $r$-th respondent. Now, the average weight coefficient for each sub-criterion set in B can be calculated by the following formulae:

$$
\bar{w}_{q}=\left[\frac{c_{q}}{\sum_{q=1}^{6} c_{q}}\right]^{-1} .
$$

Finally, the normalized average weight coefficients are to be calculated and used in (1) for pondering the sums of zero, or one values for each criterion, and per each of the considered ports $(n=\overline{1,8})$ :

$$
\bar{w}_{q n}=\frac{\bar{w}_{q}}{\sum_{q=1}^{6} \bar{w}_{q n}} .
$$

The ranking of B set subsets of criteria (B1...B6) according to their significance, carried out by ten respondents is demonstrated in Table 10.

Also, the normalized average weight coefficients per each B criteria subsets (B1...B6) are given in the last column $\left(\bar{w}_{q n}, q=\overline{1,6}\right)$. These weight coefficients have been calculated by the formulae (4), and on the basis of the previously realized calculus (2) and (3).

Since the consistency of the respondents ranking is important in making conclusions regarding the ports

Table 10. Ranking of the B criteria sub-sets (B1...B6) in the respondent questionnaires

\begin{tabular}{ccccccccccccc}
\hline & \multicolumn{10}{c}{ Respondent No. } & Sum of ranks & $\bar{w}_{q n}, q=1,6$ \\
& 1 & 2 & 3 & 4 & 5 & 6 & 7 & 8 & 9 & 10 & 12 & 0.3689 \\
\hline B1 & 1 & 1 & 1 & 1 & 2 & 2 & 1 & 1 & 1 & 1 & 22 & 0.2012 \\
\hline B2 & 2 & 2 & 2 & 2 & 3 & 3 & 2 & 2 & 2 & 2 & 59 \\
\hline B3 & 6 & 5 & 6 & 6 & 6 & 6 & 6 & 6 & 6 & 6 & 59 & 0.0750 \\
\hline B4 & 5 & 4 & 3 & 3 & 1 & 1 & 3 & 3 & 3 & 3 & 29 & 0.1527 \\
\hline B5 & 3 & 6 & 4 & 4 & 4 & 4 & 4 & 4 & 4 & 4 & 41 & 0.1079 \\
\hline B6 & 4 & 3 & 5 & 5 & 5 & 5 & 5 & 5 & 5 & 5 & 47 & 0.0942 \\
\hline Total & 21 & 21 & 21 & 21 & 21 & 21 & 21 & 21 & 21 & 21 & 210 & 1.0000 \\
\hline
\end{tabular}


final mutual positions, in following subsection of the article the concordance coefficient value has been calculated as the measure of reconciliation of the respondents' attitudes towards the considered issue.

\subsection{The Respondents' Estimates Consistency}

In order to examine the level of consistency of the respondents' estimates (Table 7), the concordance coefficient $W$ is to be calculated as:

$$
W=\frac{12 S}{r^{2} q\left(q^{2}-1\right)},
$$

where: $S=\sum_{q=1}^{6}\left(c_{q}-\sum_{q=1}^{6} c_{q}\right)^{2}-$ is analogue to the variance of the ranks; $r$ - is the number of the respondents; $q$ - is the number of the sub-criteria sets in B (B1...B6).

Now, the smallest value of $W$, i.e. $W_{\min }$ is to be calculated by the formulae:

$$
W_{\min }=\frac{\chi_{\alpha, v}^{2}}{r(q-1)},
$$

where: $\chi_{\alpha, v}^{2}-$ is critical chi-square statistics, found in the table (Montgomery 2012) by assuming the degree of freedom $v=6-1$, and the significant level $\alpha=0.010$. Here, it is $\chi_{\alpha, v}^{2}=15.09$. By taking into account the previous assumptions $W_{\min }=0.3018$, while $W=0.8514$. Since the condition $W_{\min } \leq W$ has been satisfied, it implies that the estimates of the respondents are consistent. The pseudo-code in Mathematica program used in the realization of the previously explained calculus is given below, in Table 11.

\subsection{The Results Presented by the Ports Perception Map}

On the basis of the previous calculus given in Sub-chapters (3.1) and (3.2), the final positions of the considered ports, according to the qualitative $B$ criterion set are obtained, and presented in Fig. 4.

The leading position in the case of the qualitative criteria analysis belongs to Constantza port. As opposed to the case when the quantitative criteria were considered, Rijeka port has significantly enhanced its position. Specifically, it is now ranked as the second port. The reasons for this progress lie in the fact that in the case of Rijeka port all B1 sub-criteria are present (i.e.

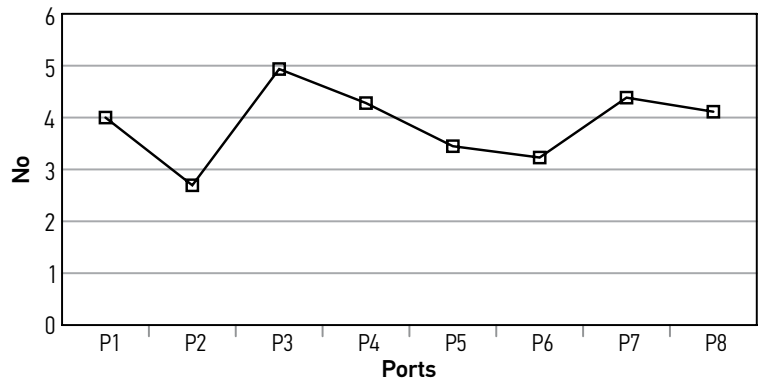

Fig. 4. Ports positions according to the quantitative criteria (B) obtained by AHP approach

each of them has value 1). Also, this port has appropriate connections with the hinterland. It is competitive in terms of ship and cargo services, while the lower degree of competitiveness exists related to the ICT applications.

Koper is slightly lower positioned than Rijeka, however, it could be concluded that they share the second position. Koper differs from Rijeka in terms of PMM (Port Management Models) criteria. It is weaker in terms of ship and cargo services, but better than Rijeka in terms of ICT solutions. Thessaloniki and Bar are sharing the fourth position. Port users perceived them as strong competitors in terms of B criteria. Users found that each of them has bottleneck regarding connections with the hinterland. Also, both ports share similar marketing, but different organizational models. Piraeus port takes lower position now, in comparison with the position previously established by the PROMETHEE method. Possible reasons are the absence of liquid cargo terminal, railway connections, and VAL (Value-Added Logistics) services. Ploce and Durres are characterized by weaker positions in relation to other six ports. Compared with Durres, Ploce port has an advantage concerning marketing variables. Therefore, the Durres port management should intensify their efforts towards the affirmation of the free zone concept and other marketing issues, but also towards the strengthening of the links with the hinterland. Ploce and Durres are different in terms of organizational models, but competitiveness factors of these two ports are largely overlapping. The results obtained here were tested among the focus group experts in this field, who agreed that the positions of the investigated ports, determined using these quantitative methods, correspond to the real situation.

Table 11. Code 2: estimating the level of consistency of respondents' estimates

Code 2: Off[General::spell1]

$\mathrm{n}=$ Input ["Number of criteria is(n):"]; $\mathrm{m}=\mathrm{Input}[$ "Number of respondents is $(\mathrm{m})$ :"]; $\mathrm{Cm}=\mathrm{Table}[0,\{\mathrm{n}\},\{\mathrm{m}\}]$;

For $[\mathrm{i}=1, \mathrm{i} \leq \mathrm{n}, \mathrm{i}++$, For $[\mathrm{j}=1, \mathrm{j} \leq \mathrm{n}, \mathrm{j}++, \mathrm{Cm}[[\mathrm{i}, \mathrm{j}]]=$ Input ["Input rank for the criterion " $<>$ ToString $[\mathrm{i}]<>$ "and respondent"

$<>$ ToString[i] $<>$ ”:"]; If $[\mathrm{Cm}=[[\mathrm{i}, \mathrm{j}]]==\$$ Canceled $\vee \mathrm{Cm}[[\mathrm{i}, \mathrm{j}]]==$ Null,Abort []$]]] ; *)$

$\mathrm{c}=\operatorname{Table}[0,\{\mathrm{n}\}] ;$ For $\left[\mathrm{i}=1 ; \mathrm{cs}=0, \mathrm{i} \leq \mathrm{n}, \mathrm{i}++, \mathrm{c}[[\mathrm{i}]]=\sum_{j=1}^{m} \operatorname{Cm}[[i, j]] ; \mathrm{cs}=\mathrm{cs}+\mathrm{c}[[\mathrm{i}]]\right] / \mathrm{n} ; S=\sum_{i=1}^{n}(c[[i]]-c s)^{2} ; W=\frac{12 S}{m^{2} n\left(n^{2}-1\right)}$;

$\chi^{2}=W m(n-1) ; \chi_{\alpha, v}^{2}=$ Input["Input the critical chi-square, from the statistical table: "]; $W_{\min }=\frac{\chi_{\alpha, v}^{2}}{m(n-1)}$;

Print ["Variance of the ranks is: $\mathrm{S}=$ ",S]; Print["The concordance coefficient is: W= ",W];

Print ["Random value $\chi^{2}$ is: $\chi^{2}=$ ",$\chi^{2}$ ]; Print ["The smallest value of $\mathrm{W}, W_{\min }$ is: $W_{\min }=$ ", $W_{\min }$ ]; If $\left[W_{\min } \leq \mathrm{W}\right.$,

Print[“The estimates of the respondents are consistent."], Print [“The estimates of the respondents are not consistent"] 


\section{Conclusions}

In this paper, the set of Adriatic, Aegean and Black Sea ports has been analyzed in order to gain an objective view of their business systems situations, having in mind that these ports have been facing great challenges of reorganization and integration into the global flows of international economics, foreign trade, maritime and inland transportation reforms, etc. With reference to both quantitative and qualitative criteria analysis, the following general observations can be given, which, to a certain extent, present the directions for marketing repositioning and development of the ports:

- According to the quantitative sub-criteria (A):

- Constantza port is the leading port according to all three analyzed sub-sets of quantitative criteria (A1, $\mathrm{A} 2$, and $\mathrm{A} 3$ ), which is not surprising, considering that one of the leading terminal operators has overtaken the initiative over this port's container terminal;

- Koper port is on the second position and its specific advantage is related to A2 group of criteria, thus this port should work on the enhancement of it's infrastructure;

- Piraeus port is on the third position in the cases of $A 1$ and $A 3$ criteria sub-sets, while in the case of $\mathrm{A} 2$, it is in a worse position than in the previous two cases. The reasons can be found in the lack of horizontal mechanisation structures, which can be one of prospective directions for the enhancement of this port's capacity;

- The positions of the other considered ports (Tessaloniki, Rijeka, Bar, Durres, and Ploce) are lower in comparison to the above mentioned ones, and they vary more or less, depending on the numerical values and nature $(\max / \mathrm{min})$ of the considered quantitative criteria. These ports must be headed towards the modernization of infrastructure, and especially horizontal and vertical mechanization assets, i.e. they need to improve the efficiency of the capacity management system, having in mind that it becomes an economically non-elastic feature in the short term. First of all, it would be especially favourable to turn towards developing a marketing concept related to the management of relationships with loyal customers in order to maintain or enhance their actual market share.

- According to the qualitative sub-criteria (B):

- The positions of most of the ports are uniform, which confirms that they are very competitiveoriented toward each other;

- The ports of Constantza, Koper and Rijeka are nearly the leaders and their development direction would be based on management and marketing variables, considering that the customers' selection greatly depends on these disciplines;

- Solun and Bar share the fourth position and they will be highly competitive, especially for the target market of South East Europe, meaning that these ports' management must consider the modernization of their hinterland connections;

- Piraeus port takes lower position in this case. The possible reasons are: absence of liquid cargo terminal, railway connections, and value-added and logistics services;

- The other two ports (Ploce and Durres) are found at lower positions than the previously ranked ones, and they need to be managed in a way that would intensify their container transhipment, considering that they have a highly competitive geo-strategic position.

Ultimately, the aim of this research work was to, using the marketing logic, as well as applying quantitative tools, clearly define the positions of these ports in terms of their competitiveness, taking into account the perceptions of users about the quantitative and qualitative criteria of their business systems. Also, the goal was to create a space for acting in the direction of defining the port development strategy. In this sense, the paper could be dedicated primarily to the management of these ports, potential investors, port authorities, as well as the wider scientific and professional community. In this context, the PROMETHEE multi-criteria quantitative optimization method allowed us to set the positions of the analyzed ports as objectively and precisely as possible. The PROMETHEE method reduces large differences in numerical values of certain criteria in order to achieve more precise positioning of the considered ports at the market, although here they are all positively correlated to the objective function. While the PROMETHEE method included a set of purely quantitative (sub) criteria, in the paper applied AHP method covered a set of qualitative (sub) criteria of the observed ports operations. Using the AHP approach, the focus of the investigation has been expanded from the internal (determinated within each port, and unchangable within a rather longer time interval) to the set that includes the external criteria, more visible to the users and more flexible in terms of adapting to their current preferences. Also, this method, in a corely qualitatve manner, provides the validation of the results obtained by the PROMETHEE method, since there are no crucial differences in the ports positions, especially the leading one.

The direction of future research work in this domain has a tendency to employ (or combine) additional quantitative, as well as qualitative methods, in order to verify the validity of the results presented by the ports perceptional maps in the paper. Also, there is a possibility to include some novel, additional, market-generated criteria for the purpose of more efficient (re) positioning of the analyzed ports.

\section{References}

Aversa, R.; Botter, R. C.; Haralambides, H. E.; Yoshizaki, H. T. Y. 2005. A mixed integer programming model on the location of a hub port in the East Coast of South America, Maritime Economics \& Logistics 7(1): 1-18. http://dx.doi.org/10.1057/palgrave.mel.9100121 
Barros, C. P. 2003. The measurement of efficiency of Portuguese sea port authorities with DEA, International Journal of Transport Economics - Rivista Internazionale de Economia dei Trasporti 30(3): 335-354.

Barros, C. P.; Athanassiou, M. 2004. Efficiency in European seaports with DEA: evidence from Greece and Portugal, Maritime Economics and Logistics 6(2): 122-140. http://dx.doi.org/10.1057/palgrave.mel.9100099

Bichou, K.; Gray, R. 2004. A logistics and supply chain management approach to port performance measurement, Maritime Policy \& Management 31(1): 47-67. http://dx.doi.org/10.1080/0308883032000174454

Brans, J. P.; Vincke, P. 1985. Note - a preference ranking organisation method: the PROMETHEE method for multiple criteria decision-making), Management Science 31(6): 647-656. http://dx.doi.org/10.1287/mnsc.31.6.647

Brans, J. P.; Vincke, P.; Mareschal, B. 1986. How to select and how to rank projects: the PROMETHEE method, European Journal of Operational Research 24(2): 228-238. http://dx.doi.org/10.1016/0377-2217(86)90044-5

Carbone, V.; De Martino, M. 2003. The changing role of ports in supply-chain management: an empirical analysis, Maritime Policy \& Management 30(4): 305-320. http://dx.doi.org/10.1080/0308883032000145618

Carbone, V.; Gouvernal, E. 2007. Supply chain and supply chain management: appropriate concepts for maritime studies, in J. Wang, D. Olivier, T. Notteboom, B. Slack (Eds.). Ports, Cities, and Global Supply Chains, 11-26.

Castillo-Manzano, J. I.; Castro-Nuño, M.; González Laxe, F.; López-Valpuesta, L.; Arévalo-Quijada, M. T. 2009. Lowcost port competitiveness index: implementation in the Spanish port system, Marine Policy 33(4): 591-598. http://dx.doi.org/10.1016/j.marpol.2008.12.008

Comtois, C.; Slack, B. 2007. Sustainable development and corporate strategies of the maritime industry, in J. Wang, D. Olivier, T. Notteboom, B. Slack (Eds.). Ports, Cities, and Global Supply Chains, 233-246.

Cullinane, K.; Wang, T.-F.; Song, D.-W.; Ji, P. 2006. The technical efficiency of container ports: comparing data envelopment analysis and stochastic frontier analysis, Transportation Research Part A: Policy and Practice 40(4): 354-374. http://dx.doi.org/10.1016/j.tra.2005.07.003

Guy, E.; Urli, B. 2006. Port selection and multicriteria analysis: an application to the Montreal-New York alternative, Maritime Economics \& Logistics 8(2): 169-186. http://dx.doi.org/10.1057/palgrave.mel.9100152

Haezendonck, E.; Pison, G.; Rousseeuw, P.; Struyf, A.; Verbeke, A. 2000. The competitive advantage of seaports, International Journal of Maritime Economics 2(2): 69-82. http://dx.doi.org/10.1057/ijme.2000.8

Heaver, T.; Meersman, H.; Moglia, F.; Van de Voorde, E. 2000. Do mergers and alliances influence European shipping and port competition?, Maritime Policy \& Management 27(4): 363-373. http://dx.doi.org/10.1080/030888300416559

Huang, W.-C.; Teng, J.-Y.; Huang, M.-J.; Kou, M.-S. 2003. Port competitiveness evaluation by fuzzy multicriteria grade classification model, Journal of Marine Science and Technology 11(1): 53-60.

Jolić, N. 2003. Quantitative simulation modelling of some functional characteristics of the intelligent transport systems for port system, in Proceedings of the 15th International Conference on System Research, Informatics and Cybernetics - InterSymp-2003, 28 July - 2 August 2003, Baden-Baden, Germany, 1-9. (CD).
Jolić, N.; Šimović, V.; Crnjac, M. 2004. Comparative analysis by stochastic simulation of basic information aspects of classical and intelligent transport system for port system, in Proceedings of the 5th EuroSim Congress on Modelling and Simulation, 6-10 September 2004, Paris, France, 1-6. (CD).

Kotler, P.; Keller, K. 2008. Marketing Management. 13th edition. Prentice Hall. 816 p.

Lirn, T. C.; Thanopoulou, H. A.; Beynon, M. J.; Beresford, A. K. C. 2004. An application of AHP on transhipment port selection: a global perspective, Maritime Economics \& Logistics 6(1): 70-91.

http://dx.doi.org/10.1057/palgrave.mel.9100093

Magala, M.; Sammons, A. 2008. A new approach to port choice modelling, Maritime Economics \& Logistics 10(1-2): 9-34. http://dx.doi.org/10.1057/palgrave.mel.9100189

Malchow, M. B.; Kanafani, A. 2004. A disaggregate analysis of port selection, Transportation Research Part E: Logistics and Transportation Review 40(4): 317-337.

http://dx.doi.org/10.1016/j.tre.2003.05.001

Montgomery, D. C. 2012. Introduction to Statistical Quality Control. 7th edition. Wiley. $768 \mathrm{p}$.

Murphy, P. R.; Daley, J. M.; Dalenberg, D. R. 1992. Port selection criteria: an application of a transportation research framework, Logistics and Transportation Review 28(3): 237-255.

Noteboom, T. E.; Winkelmans, W. 2001. Structural changes in logistics: how will port authorities face the challenge?, Maritime Policy \& Management 28(1): 71-89. http://dx.doi.org/10.1080/03088830119197

Notteboom, T.; Yap, W. Y. 2012. Port competition and competitiveness, in W. K. Talley (Ed.). The Blackwell Companion to Maritime Economics, 549-570. http://dx.doi.org/10.1002/9781444345667.ch27

Notteboom, T. E.; Rodrigue, J.-P. 2005. Port regionalization: towards a new phase in port development, Maritime Policy \& Management 32(3): 297-313. http://dx.doi.org/10.1080/03088830500139885

Panayides, P. M.; Maxoulis, C. N.; Wang, T.-F.; Ng, K. Y. A. 2009. A critical analysis of DEA applications to seaport economic efficiency measurement, Transport Reviews 29(2): 183-206. http://dx.doi.org/10.1080/01441640802260354

Panayides, P. M.; Song, D.-W. 2009. Port integration in global supply chains: measures and implications for maritime logistics, International Journal of Logistics: Research and Applications 12(2): 133-145.

http://dx.doi.org/10.1080/13675560902749407

Pando, J.; Araujo, A.; Maqueda, F. J. 2005. Marketing management at the world's major ports, Maritime Policy \& Management 32(2): 67-87. http://dx.doi.org/10.1080/03088830500097414

Pardali, A.; Michalopoulos, V. 2008. Determining the position of container handling ports, using the benchmarking analysis: the case of the port of Piraeus, Maritime Policy \& Management 35(3): 271-284. http://dx.doi.org/10.1080/03088830802080316

Petrović, R.; Šenborn, A.; Vujošević, M. 1988. Multicriteria ranking of spares allocations, Naval Research Logistics 35(6): 707-717.

http://dx.doi.org/10.1002/1520-6750(198812)35:6<707::AI D-NAV3220350614>3.0.CO;2-V

Poletan-Jugović, T.; Jolić, N.; Kavran, Z. 2009. Comparative analysis of cargo flows on branches VB and VC of the Pan-European corridor V, Promet - Traffic\&Transportation 21(3): 205-216. http://dx.doi.org/10.7307/ptt.v21i3.227 
Robinson, R. 2002. Ports as elements in value-driven chain systems: the new paradigm, Maritime Policy \& Management 29(3): 241-255.

http://dx.doi.org/10.1080/03088830210132623

Rugman, A. M.; Verbeke, A. 1993. How to operationalize porter's diamond of international competitiveness, The International Executive 35(4): 283-299. http://dx.doi.org/10.1002/tie.5060350403

Saaty, T. L. 1977. A scaling method for priorities in hierarchical structures, Journal of Mathematical Psychology 15(3): 234-281. http://dx.doi.org/10.1016/0022-2496(77)90033-5

Saaty, T. L. 1994a. How to make a decision: the analytic hierarchy process, Interfaces 24(6): 19-43. http://dx.doi.org/10.1287/inte.24.6.19

Saaty, T. L. 1994b. Homogeneity and clustering in AHP ensures the validity of the scale, European Journal of Operational Research 72(3): 588-601. http://dx.doi.org/10.1016/03772217(94)90426-X

Saaty, T. L. 2003. Decision-making with the AHP: why is the principal eigenvector necessary, European Journal of Operational Research 145(1): 85-91.

http://dx.doi.org/10.1016/S0377-2217(02)00227-8

Sivilevičius, H.; Maskeliūnaitè, L. 2010. The criteria for identifying the quality of passengers' transportation by railway and their ranking using AHP method, Transport 25(4): 368-381. http://dx.doi.org/10.3846/transport.2010.46

Slack, B. 1985. Containerization, inter-port competition, and port selection, Maritime Policy \& Management 12(4): 293303. http://dx.doi.org/10.1080/03088838500000043

Slack, B. 2007. The terminalisation of seaports, in J. Wang, D. Olivier, T. Notteboom, B. Slack (Eds.). Ports, Cities, and Global Supply Chains, 41-50.

Song, D.-W.; Yeo, K.-T. 2004. A competitive analysis of chinese container ports using the analytic hierarchy process, Maritime Economics \& Logistics 6(1): 34-52. http://dx.doi.org/10.1057/palgrave.mel.9100096

Shikin, E. V.; Chhartishvili, A. G. 2002. Matematicheskie Metody i Modeli v Upravlenii. Delo, Moskva. 440 s. (in Russian).

Tongzon, J. L. 1995. Systematizing international benchmarking for ports, Maritime Policy \& Management 22(2): 171-177. http://dx.doi.org/10.1080/03088839500000048

Tongzon, J. 2001. Efficiency measurement of selected Australian and other international ports using data envelopment analysis, Transportation Research Part A: Policy and Practice 35(2): 107-122.

http://dx.doi.org/10.1016/S0965-8564(99)00049-X

Tongzon, J.; Heng, W. 2005. Port privatization, efficiency and competitiveness: some empirical evidence from container ports (terminals), Transportation Research Part A: Policy and Practice 39(5): 405-424. http://dx.doi.org/10.1016/j.tra.2005.02.001

Tongzon, J. L. 2009. Port choice and freight forwarders, Transportation Research Part E: Logistics and Transportation Review 45(1): 186-195. http://dx.doi.org/10.1016/j.tre.2008.02.004

Vickery, S. K.; Jayaram, J.; Droge, C.; Calantone, R. 2003. The effects of an integrative supply chain strategy on customer service and financial performance: an analysis of direct versus indirect relationships, Journal of Operations Management 21(5): 523-539. http://dx.doi.org/10.1016/j.jom.2003.02.002

Wang, T.-F.; Cullinane, K. 2006. The efficiency of european container terminals and implications for supply chain management, Maritime Economics \& Logistics 8(1): 82-99. http://dx.doi.org/10.1057/palgrave.mel.9100151
Yeo, G.-T.; Roe, M.; Dinwoodie, J. 2008. Evaluating the competitiveness of container ports in Korea and China, Transportation Research Part A: Policy and Practice 42(6): 910-921. http://dx.doi.org/10.1016/j.tra.2008.01.014

Yeo, G.-T.; Song, D.-W. 2006. An application of the hierarchical fuzzy process to container port competition: policy and strategic implications, Transportation 33(4): 409-422. http://dx.doi.org/10.1007/s11116-005-6000-4 